\title{
Germline mutation in the RAD51B gene confers predisposition to breast cancer
}

\author{
Lisa Golmard ${ }^{1,2^{*}}$, Virginie Caux-Moncoutier ${ }^{1 \dagger}$, Grégoire Davy ${ }^{1}$, Essam Al Ageeli ${ }^{1}$, Brigitte Poirot ${ }^{1}$, Carole Tirapo ${ }^{1}$, \\ Dorothée Michaux', Catherine Barbaroux', Catherine Dubois d'Enghien', André Nicolas', Laurent Castéra', \\ Xavier Sastre-Garau ${ }^{1}$, Marc-Henri Stern ${ }^{1,2}$, Claude Houdayer ${ }^{1,2,3}$ and Dominique Stoppa-Lyonnet ${ }^{1,2,3}$
}

\begin{abstract}
Background: Most currently known breast cancer predisposition genes play a role in DNA repair by homologous recombination. Recent studies conducted on RAD51 paralogs, involved in the same DNA repair pathway, have identified rare germline mutations conferring breast and/or ovarian cancer predisposition in the RAD51C, RAD51D and XRCC2 genes. The present study analysed the five RAD51 paralogs (RAD51B, RAD51C, RAD51D, XRCC2, XRCC3) to estimate their contribution to breast and ovarian cancer predisposition.

Methods: The study was conducted on 142 unrelated patients with breast and/or ovarian cancer either with early onset or with a breast/ovarian cancer family history. Patients were referred to a French family cancer clinic and had been previously tested negative for a BRCA1/2 mutation. Coding sequences of the five genes were analysed by EMMA (Enhanced Mismatch Mutation Analysis). Detected variants were characterized by Sanger sequencing analysis.

Results: Three splicing mutations and two likely deleterious missense variants were identified: $R A D 51 B c .452+3 A>G$, RAD51C c.706-2A > G, RAD51C c.1026 + 5_1026 + 7del, RAD51B c.475C > T/p.Arg159Cys and XRCC3 c.448C > T/p. Arg150Cys. No RAD51D and XRCC2 gene mutations were detected. These mutations and variants were detected in families with both breast and ovarian cancers, except for the RAD51B C.475C > T/p.Arg159Cys variant that occurred in a family with 3 breast cancer cases.

Conclusions: This study identified the first RAD51B mutation in a breast and ovarian cancer family and is the first report of XRCC3 mutation analysis in breast and ovarian cancer. It confirms that RAD51 paralog mutations confer breast and ovarian cancer predisposition and are rare events. In view of the low frequency of RAD51 paralog mutations, international collaboration of family cancer clinics will be required to more accurately estimate their penetrance and establish clinical guidelines in carrier individuals.
\end{abstract}

Keywords: Genetic predisposition, Breast cancer, Ovarian cancer, RAD51 paralogs, RAD51B

\section{Background}

Breast cancer is currently the most common cancer and the leading cause of cancer deaths in women worldwide [1]. Abnormal familial aggregations fitting a model of autosomal dominant breast cancer genetic predisposition account for about $5 \%$ of cases [2]. BRCA1 and BRCA2 are the two major genes, but explain only about $20 \%$ of inherited breast cancers [3-5]. About ten genes are

\footnotetext{
* Correspondence: lisa.golmard@curie.net

${ }^{\dagger}$ Equal contributors

'Institut Curie, Department of Tumour Biology, 26 rue d'Ulm, 75248, Paris, Cedex 05, France

${ }^{2}$ Institut Curie, INSERM U830, 26 rue d'UIm, 75248, Paris, Cedex 05, France Full list of author information is available at the end of the article
}

known to be involved in breast cancer predisposition, either isolated or associated with other cancers, with variable breast cancer risks. Approximately $50 \%$ of familial breast cancers remain unresolved by any of these genes after genetic testing [6].

Most currently known breast cancer predisposition genes play a role in the repair of DNA double-strand breaks by homologous recombination: BRCA1 and $B R C A 2$, associated with a high risk of breast cancer, and BRIP1 and PALB2, associated with a moderate risk [7-9]. While breast cancer predisposition is conferred by mono-allelic germline mutations in these genes, bi-allelic germline mutations in BRCA2, BRIP1 and PALB2 result in Fanconi anaemia, an

\section{Biomed Central}


autosomal recessive inherited syndrome characterized by multiple developmental abnormalities and predisposition to various cancers [10-12].

Genetic studies were recently conducted on the RAD51 paralogs, involved in the same DNA repair pathway: BRCA2 protein loads RAD51 monomers at DNA doublestrand break sites; RAD51 recruitment also depends on the RAD51 paralog family [13]. Bi-allelic mutations resulting in Fanconi anaemia were identified in $R A D 51 C$ and XRCC2 [14,15]. Mono-allelic germline mutations conferring breast and ovarian cancer predisposition were identified in $R A D 51 C$ and $R A D 51 D$ [16,17]. XRCC2 mutations were then detected in breast cancer families but a subsequent population-based study failed to confirm an association between $X R C C 2$ variants and breast cancer risk $[18,19]$. Johnson et al. conducted a study on $R A D 51 B$ in breast cancer families and did not detect any mutations [20]. The XRCC3 gene has not yet been studied.

In this study, we analysed the five $R A D 51$ paralogs (RAD51B, RAD51C, RAD51D, XRCC2, XRCC3) in 142 unrelated patients with breast and/or ovarian cancer to estimate their contribution to breast and ovarian cancer predisposition.

\section{Methods}

\section{Patients}

The study was conducted on 142 unrelated patients with breast and/or ovarian cancer either with early onset or with a breast/ovarian cancer family history. Patients had been previously tested negative for a $B R C A 1 / 2$ mutation, selected either for a predisposition probability higher than $70 \%$ according to the Claus model [2] or for enrichment in ovarian cancer cases: 87 patients $(61 \%)$ had a personal or family history of both breast and ovarian cancer, 10 patients $(7 \%)$ had a personal or family history of ovarian cancer only and 45 patients (32\%) had a personal or family history of breast cancer only (Table 1). All patients

\begin{tabular}{ll}
$\begin{array}{l}\text { Table } \mathbf{1} \text { Patient personal and family history of breast/ } \\
\text { ovarian cancer }\end{array}$ & $\mathbf{n}(\%)$ \\
\hline Personal and family history & $4(3)$ \\
\hline Personal history & $6(4)$ \\
Ovarian adenocarcinoma before the age of 70 & $1(1)$ \\
Breast adenocarcinoma and ovarian cancer & \\
Breast adenocarcinoma before the age of 36 & $81(57)$ \\
Family history* & $36(25)$ \\
2 ovarian cancer cases & $8(6)$ \\
2 breast cancer cases & $6(4)$ \\
\hline breast cancer cases & breast cancer case and 1 ovarian cancer case
\end{tabular}

*Family history was defined in first- or second-degree relatives in the same lineage. attended a visit with a geneticist and a genetic counsellor in a family cancer clinic, mostly at the Institut Curie, Paris, France. Patients gave their informed consent for genetic testing. The study was approved by the local Ethics Committee in Institut Curie.

\section{Genomic DNA analysis}

Genomic DNA was extracted from $2 \mathrm{~mL}$ whole-blood samples collected on EDTA with the Quickgene 610-L automated system (Fujifilm) according to the manufacturer's instructions. RAD51 paralog mutation screening was performed on coding exons and exon-intron junctions by multiplex PCR and Enhanced Mismatch Mutation Analysis (EMMA) [21] except for 2 RAD51B exons which were analysed by simplex PCR and direct sequencing (Additional file 1: Table S1 and Additional file 2: Table S2). PCR products showing abnormal EMMA profiles were analysed by sequencing on an ABI PRISM 3130XL Genetic analyzer (Applied Biosystems).

\section{mRNA analysis for RAD51C splicing mutations}

RNA was extracted from lymphoblastoid cell lines using TRIzol reagent according to the manufacturer's instructions (Invitrogen). $2 \mu \mathrm{g}$ of total RNA from each sample was used for reverse transcription in a $40 \mu \mathrm{L}$ reaction using the GeneAmp RNA PCR Core kit according to the manufacturer's instructions (Applied Biosystems). cDNA was amplified with forward and reverse primers GCATTCAGCACCTTCAGCTT and CTTTCGGTCCCAATGAAAGA for RAD51C exon 5 skipping, TGACCTGTCTCTTCGTACTCG and for $R A D 51 C$ exon 8 skipping.

\section{RAD51B immunohistochemistry}

For RAD51B immunostaining, 4- $\mu$ m-thick paraffin sections were cut and mounted on glass slides (Superfrost+, Menzel Glazer). Preparations were dried for one hour at $58^{\circ} \mathrm{C}$, then overnight at $37^{\circ} \mathrm{C}$. Sections were deparaffined with toluene and rehydrated with ethanol. Preparations were pretreated with citrate buffer $(0.01 \mathrm{M}$ citric acid $\mathrm{pH}$ 6.0), and a heat-based antigen retrieval method was used prior to incubations. Endogenous peroxidase was blocked using 3\% hydrogen peroxidase solution for $5 \mathrm{mi}$ nutes. The primary anti-RAD51B antibody used (clone NBP1-66539, dilution 1/200) was from Novus Biologicals. Sections were incubated for 15 minutes at $22^{\circ} \mathrm{C}$ with the primary antibody followed by staining with anti-rabbit HRP antibody (Leica Biosystems) for 10 minutes. Sections were then revealed in a diaminobenzidine solution for 15 minutes and stained with hematoxylin for 7 minutes.

\section{Missense variants pathogenic prediction}

Three bioinformatics tools were used for missense variants pathogenic prediction: Align-GVGD [22,23], SIFT $[24,25]$ and Polyphen-2 [26,27]. Multiple sequence 
alignment (MSA) for Align-GVGD and SIFT analysis was an alignment of protein sequences of 11 species: Human (Homo sapiens), Chimpanzee (Pan troglodytes), Macaque (Macaca mulatta), Mouse (Mus musculus), Rabbit (Oryctolagus cuniculus), Dog (Canis familiaris), Cat (Felis catus), Bovine (Bos taurus), Opossum (Monodelphis domestica), Platypus (Ornithorynchus anatinus), Chicken (Gallus gallus) and Frog (Xenopus tropicalis). Missense variants were interpreted as likely deleterious if they were classified as deleterious or probably damaging by the three tools.

\section{Statistical analysis}

Frequencies of mutations and likely deleterious variants were compared between the cases and two control samples from online databases: European-American controls from Exome Variant Server [28] and European controls from 1000 Genomes project [29]. In a first step the two control sample variant frequencies were compared using Fisher's exact test in order to check there was no significant difference. In a second step the control samples were pooled and the overall control variant frequency was compared with the case sample one, using Fisher's exact test. All the tests were two-sided, with a p-value of 0.05 considered significant. Computations were performed using the XLSTAT-2013 software.

\section{Results}

Three splicing mutations and two likely deleterious missense variants were identified in these 142 patients: $R A D 51 B$ c. $452+3 \mathrm{~A}>\mathrm{G}, R A D 51 C$ c. $706-2 \mathrm{~A}>\mathrm{G}, R A D 51 C$ c. $1026+5 \_1026+7 \mathrm{del}, \quad R A D 51 B$ c.475C > T/p.Arg159Cys and XRCC3 c.448C > T/p.Arg150Cys (Table 2). No mutation was detected in the RAD51D and XRCC2 genes (See Additional file 3: Table S3 for all variants and polymorphisms detected in this study).

All variants detected on DNA were tested by in silico splicing effect prediction according to a previously published pipeline [30]: a greater than 15\% decrease of the MaxEntScan score for donor/acceptor splice sites and a greater than 5\% decrease of the SpliceSiteFinder-like score for donor/acceptor splice sites were considered to be significant with $96 \%$ sensitivity and $83 \%$ specificity. Three variants were likely to alter splicing according to this pipeline: $R A D 51 C$ c.706-2A $>\mathrm{G}$ and c.1026 + 5_1026 + 7del, and $R A D 51 B$ c. $452+3 \mathrm{~A}>\mathrm{G}$. Exon skipping was confirmed by mRNA analysis for the two RAD51C mutations (Figure 1). No RNA was available to study the impact of the $R A D 51 B$ c. $452+3 \mathrm{~A}>\mathrm{G}$ mutation but, using immunohistochemistry with anti-RAD51B antibody, loss of expression of RAD51B protein was observed in breast carcinoma cells from the patient bearing this mutation, as compared with that detected in the nucleus of normal duct cells (Figure 2).
Likely deleterious missense variants reported in this study in the $R A D 51 B$ and $X R C C 3$ genes are located in the ATP-binding domain of the proteins and result in the replacement of highly conserved amino acids with subsequent high Grantham score (Table 2).

Mutations and likely deleterious variants were detected in families with both breast and ovarian cancers, except for the RAD51B p.Arg159Cys variant that occurred in a family with 3 breast cancer cases (Figure 3 ). The $R A D 51 C$ c.706-2A > G mutation co-segregated with an ovarian cancer at the age of 67 years for a paternal aunt of the index case. No other co-segregation studies have been performed to date.

\section{Discussion}

This study reports RAD51 paralog analysis in breast and ovarian cancer cases. To our knowledge, this is the first report of a $R A D 51 B$ mutation and evaluation of the contribution of the XRCC3 gene to breast and ovarian cancer predisposition.

\section{RAD51B gene}

We identified a $R A D 51 B$ mutation and a likely deleterious variant in two patients: the RAD51B c. $452+3 \mathrm{~A}>\mathrm{G}$ mutation was detected in a breast and ovarian cancer family case and the $R A D 51 B$ p.Arg159Cys variant was detected in a family with 3 breast cancer cases.

$R A D 51 B$ has been previously evaluated as a candidate gene for breast cancer predisposition but no mutation was detected in a study of 188 multiple breast cancer family cases (Johnson et al. [20]). The low frequency of $R A D 51 B$ mutations may account for the differences observed between our results and those reported by Johnson et al., as previously described for $R A D 51 C, R A D 51 D$ and $X R C C 2$ [16-18]. More generally concerning $R A D 51 B$ involvement in cancer, previous studies have identified chromosomal rearrangements disrupting $R A D 51 B$ in benign tumours, particularly uterine leiomyomas [31,32]. Overall, haploinsufficiency of $R A D 51 B$ was shown to induce genomic instability in human cells, suggesting its involvement in cancer predisposition [33]. In addition, our findings must be interpreted in the context of two genome-wide association studies (GWAS) that identified the minor allele of single nucleotide polymorphisms (SNPs) in RAD51B acting as low risk factors for breast cancer: rs999737 [34] and rs1314913 [35], located in $R A D 51 B$ introns 10 and 7 , respectively. Overall, these findings might indicate that $R A D 51 B$ acts as a susceptibility factor or as a major gene depending on the context. Indeed, it cannot be excluded that the minor allele of these SNPs indirectly reflects a major influence of $R A D 51 B$ [36], as a recent study showed that high risk rare mutations can account for some synthetic associations identified by GWAS [37]. 
Table 2 Mutations and likely deleterious variants, their effect on splicing or protein, cancer history of carriers

\begin{tabular}{|c|c|c|c|c|c|c|c|}
\hline Gene & $\begin{array}{l}\text { Genetic } \\
\text { variation }\end{array}$ & Variant class & Effect on splicing & $\begin{array}{l}\text { Predicted effect on protein } \\
\text { (Align-GVGD class }{ }^{\dagger} \text { ) }\end{array}$ & $\begin{array}{l}\text { Personal cancer } \\
\text { history (age at } \\
\text { diagnosis) }\end{array}$ & Family cancer history (age at diagnosis) & Controls $^{\ddagger}$ \\
\hline RAD51B & $c .452+3 A>G$ & $\begin{array}{l}\text { Splicing } \\
\text { mutation }\end{array}$ & $\begin{array}{l}\text { Exon } 5 \text { skipping by } \\
\text { in silico prediction* }\end{array}$ & $\begin{array}{l}\text { Unstable or truncated protein, } \\
\text { confirmed by negative } \mathrm{IHC}\end{array}$ & BC (34) & Paternal aunt, BC (58); $3^{\text {rd }}$ degree relative, OC (29) & - \\
\hline RAD51B & $\begin{array}{l}\text { c. } 475 C>T \text {, p. } \\
\text { Arg159Cys }\end{array}$ & $\begin{array}{l}\text { Likely } \\
\text { deleterious } \\
\text { missense variant }\end{array}$ & No predicted effect & $\begin{array}{l}\text { ATP-binding domain, highly } \\
\text { conserved amino acid, Grantham } \\
180 \text { (Class C65) }\end{array}$ & BC (54) & Sister, BC (45); Sister's daughter BC (45) & $2 / 4299$ \\
\hline RAD51C & c. $706-2 A>G$ & $\begin{array}{l}\text { Splicing } \\
\text { mutation }\end{array}$ & $\begin{array}{l}\text { Exon } 5 \text { skipping } \\
\text { confirmed by mRNA } \\
\text { analysis }\end{array}$ & $\begin{array}{l}44 \text { amino acids loss in ATP-binding } \\
\text { domain }\end{array}$ & BC (39) & Paternal aunt ${ }^{\S}, \mathrm{OC}(67)$ & - \\
\hline RAD51C & $\begin{array}{l}\text { c. } 1026+ \\
5 \_1026+7 \mathrm{del}\end{array}$ & $\begin{array}{l}\text { Splicing } \\
\text { mutation }\end{array}$ & $\begin{array}{l}\text { Exon } 8 \text { skipping } \\
\text { confirmed by mRNA } \\
\text { analysis }\end{array}$ & Unstable or truncated protein & $\mathrm{BC}(38), \mathrm{OC}(51)$ & $\begin{array}{l}\text { Father, PC (69); Paternal grandmother, UC (66); Paternal } \\
\text { grandfather, SC (69) }\end{array}$ & - \\
\hline XRCC3 & $\begin{array}{l}\text { c. } 448 C>\text { C, p. } \\
\text { Arg150Cys }\end{array}$ & $\begin{array}{l}\text { Likely } \\
\text { deleterious } \\
\text { missense variant }\end{array}$ & No predicted effect & $\begin{array}{l}\text { ATP-binding domain, highly } \\
\text { conserved amino acid, Grantham } 180 \\
\text { (Class C65) }\end{array}$ & $B C(63)$ & $\begin{array}{l}\text { Mother, OC (61); Maternal aunt, BC (55); Maternal aunt, BC } \\
\text { (73); Maternal aunt, BC (76); Maternal aunt, BC }(63,79)\end{array}$ & $1 / 4276$ \\
\hline
\end{tabular}




\section{A Control}
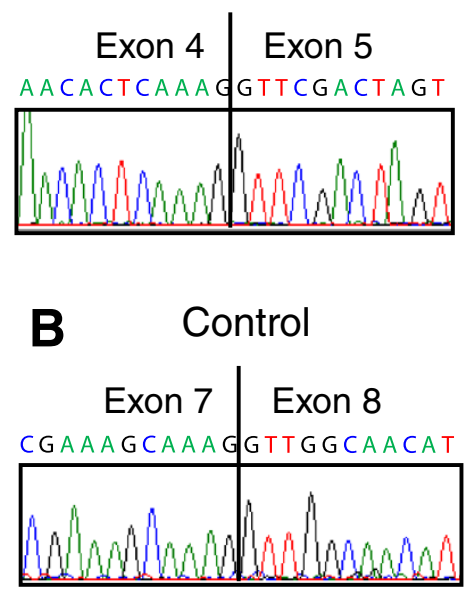

RAD51C c.706-2A>G

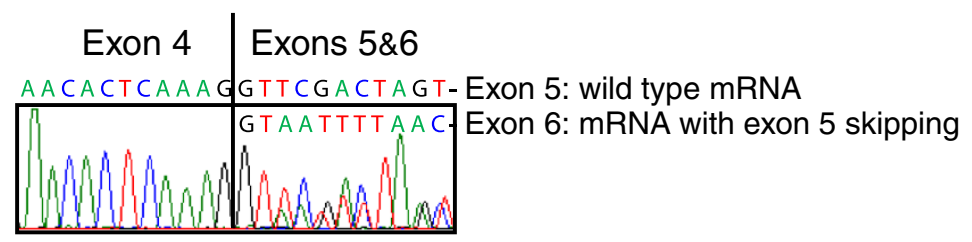

RAD51C c.1026+5_1026+7del

Exon 7 Exons 8\&9

CGAAAGCAAAGGTGGCAACAT- Exon 8: wild type mRNA

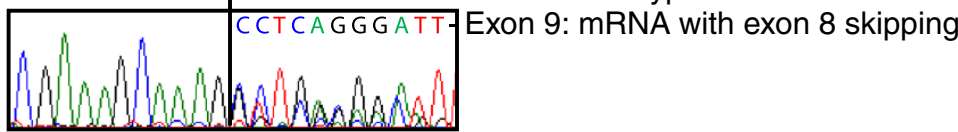

Figure 1 mRNA analysis for RAD51C splicing mutations showing exon skipping. (A) Electropherograms of Sanger sequencing analysis for a control sample with wild type RAD51C mRNA only (left) and for RAD51C c.706-2A > G mutation with two types of mRNA: wild type mRNA and mRNA with exon 5 skipping (right). (B) Electropherograms of Sanger sequencing analysis for a control sample with wild type RAD51C mRNA only (left) and for RAD51C c.1026+5_1026 + 7del mutation with two types of mRNA: wild type mRNA and mRNA with exon 8 skipping (right).

$R A D 51 B$ c. $452+3 \mathrm{~A}>\mathrm{G}$ is a novel mutation. Several arguments strongly support its causality: this variation is absent in the thousands of controls tested in online databases (Exome Variant Server [28], dbSNP [38], 1000 Genomes [29]); in silico prediction concluded this variation was likely to result in an out-of-frame exon skipping leading to a truncated or unstable protein; RAD51B immunohistochemistry in breast carcinoma cells of the patient bearing this variation showed a loss of expression of RAD51B.
The $R A D 51 B$ p.Arg159Cys variant is reported in Exome Variant Server: this variant was detected in 2 out of 4,299 controls in European-American populations. We consider this variant to be a likely deleterious variant because it occurs in a functional domain and results in replacement of a highly conserved amino acid with subsequent high Grantham score and Align-Grantham Variation Grantham Deviation (Align-GVGD) maximum score (C65), and very low frequencies are reported in Exome Variant Server. Its

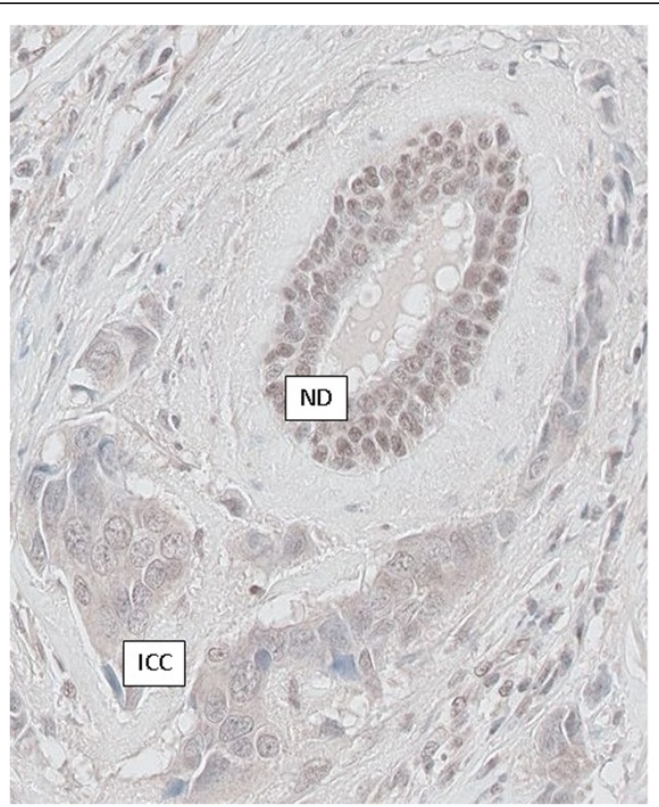

Figure 2 RAD51B immunohistochemistry in breast tissue of patient carrying the RAD51B c.452 + 3A > G mutation. A brown staining of moderate intensity is observed in the nucleus of non tumor epithelial cells located in normal duct (ND) of the breast tissue. In comparison, no significant staining is detected in the nucleus of invasive carcinoma cells (ICC). 
RAD51B

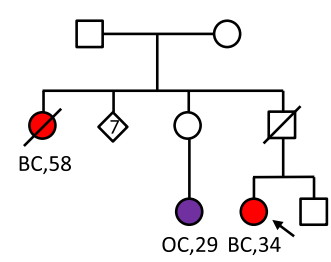

c. $452+3 A>G$

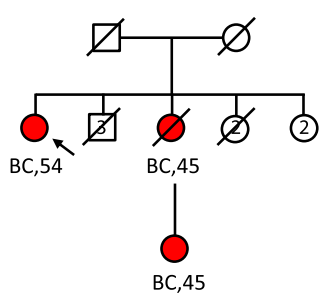

c. 475 C > T/p.Arg159Cys

\section{XRCC3}

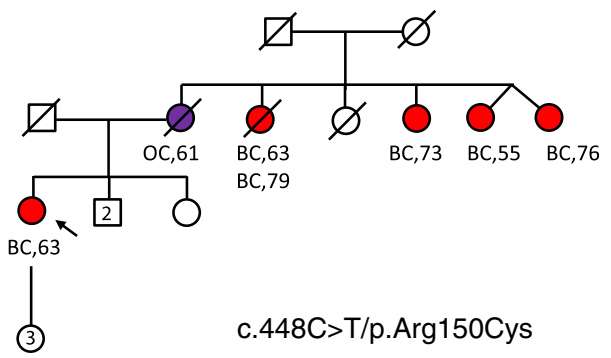

\section{RAD51C}

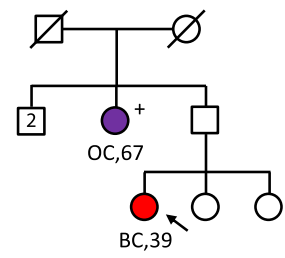

c. $706-2 A>G$

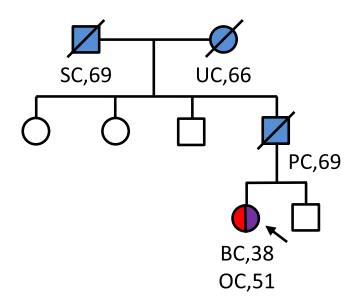

c. $1026+5 \_1026+4$ del

Figure 3 Pedigrees for RAD51 paralog mutation and likely causal variant carriers. Individuals with breast cancer (BC) are shown as red circles, ovarian cancer (OC) as purple circles, and other cancers as blue circles. SC: stomach cancer; UC: uterine cancer; PC: pancreas cancer. Disease and age in years at diagnosis are given underneath the symbol. The index case is indicated with an arrow. No co-segregation studies have yet been performed, except for RAD51C c.706-2A > G: tested relative with OC carried the mutation, indicated by (+).

occurrence in controls could be explained by an incomplete penetrance.

Overall, for the $R A D 51 B$ gene, one truncating mutation and one likely deleterious variant were detected in 2 out of 142 patients selected for enrichment in breast/ovarian cancer cases. In online databases, one truncating mutation and two likely deleterious variants were detected in 4 out of 4,678 controls (Additional file 4: Table S4). Frequency of RAD51B variants was significantly higher in cases $(\mathrm{p}=0.012)$, which suggests $R A D 51 B$ variants are associated with breast/ovarian cancer risks.

\section{$X R C C 3$ gene}

The XRCC3 p.Arg150Cys variant was detected in a family with 1 ovarian cancer and 5 breast cancer cases. Like the $R A D 51 B$ missense variant reported in this study, the $X R C C 3$ p.Arg150Cys variant is reported with a very low frequency in Exome Variant Server (1 out of 4,276 controls in European-American populations). We consider this variant to be a likely deleterious variant because it occurs in a functional domain and results in replacement of a highly conserved amino acid with subsequent high Grantham score and Align-GVGD maximum score (C65).

This study is the first report of XRCC3 mutation screening in breast and ovarian cancer predisposition. Numerous association studies have evaluated XRCC3 SNPs as candidate risk factors for breast cancer, but the results of these studies remain controversial. A recent meta-analysis suggested that the minor allele of XRCC3 p.Thr241Met SNP was a low risk factor and XRCC3 IVS5-14A > G SNP a low protective factor for breast cancer [39].

\section{RAD51C gene}

Several studies have reported $R A D 51 C$ causal mutations in breast and ovarian cancer predisposition $[16,40,41]$. Two novel $R A D 51 C$ splicing mutations are reported in this study: RAD51C c.1026+5_1026+7del mutation is truncating, resulting in an out-of-frame exon 8 skipping and $R A D 51 C$ c.706-2A $>$ G mutation leads to the loss of 44 amino acids in a functional domain of the protein by an in-frame exon 5 skipping. These two RAD51C mutations were detected in families with both breast and ovarian cancer cases, which is consistent with previous studies. As this set of patients was enriched with ovarian cancer cases and due to the low frequency of $R A D 51 C$ mutations, other studies must be conducted in larger series to evaluate whether $R A D 51 C$ confers predisposition to ovarian cancer alone or to both breast and ovarian cancer, which remains controversial [42].

\section{Conclusions}

This study identified the first $R A D 51 B$ mutation in a breast and ovarian cancer family and confirmed that RAD51 paralog mutations confer breast and ovarian cancer predisposition and are rare events. Identification 
of families with mutations in the RAD51B, RAD51C or $X R C C 3$ genes and genetic testing of family members could be used to estimate the associated breast and ovarian cancer risks. In view of the low frequency of RAD51 paralog mutations, international collaboration of family cancer clinics will be required to more accurately estimate their penetrance and establish clinical guidelines. Such studies would be facilitated by the development of Next Generation Sequencing allowing laboratories to simultaneously analyse numerous genes.

\section{Additional files}

Additional file 1: Table S1. Multiplex PCR mixes.

Additional file 2: Table S2. Primers.

Additional file 3: Table S3. All variants and polymorphisms detected in this study.

Additional file 4: Table S4. $R A D 51 B$ variants in cases and controls.

\section{Abreviations}

EMMA: Enhanced mismatch mutation analysis; Align-GVGD: Align-Grantham variation Grantham deviation; GWAS: Genome-wide association studies; SNP: Single nucleotide polymorphism; ND: Normal duct; ICC: Invasive carcinoma cells; BC: Breast cancer; OC: Ovarian cancer; SC: Stomach cancer; UC: Uterine cancer; PC: Pancreas cancer.

\section{Competing interests}

The authors declare that they have no competing interests.

\section{Authors' contribution}

LG evaluated and interpreted the data, and wrote the paper. VM was involved in design of mutation analysis by EMMA and Sanger sequencing, data analysis and interpretation. GD, EA, BP, CT, DM, CB and CDD performed part of the mutation analysis and interpretation of the data. LC analysed and evaluated part of the data of mutation analysis. AN and XSG were involved in design, evaluation and interpretation of the data of RAD51B immunohistochemistry. MHS, CH and DSL were involved in conception and design of the study, data interpretation and writing the paper. All authors have critically revised and approved the submitted paper.

\section{Acknowledgements}

We thank Isabelle Eugène, Catherine Gilbon, Karin Maciotta, Sandrine Miglierina and Catherine Rougeron for helpful support during the course of this study, and the Institut Curie Breast Cancer group for referring patients. This work was supported by INCa Recherche Translationnelle grant number 4521000377.

\section{Author details}

${ }^{1}$ Institut Curie, Department of Tumour Biology, 26 rue d'Ulm, 75248, Paris, Cedex 05, France. ${ }^{2}$ Institut Curie, INSERM U830, 26 rue d'Ulm, 75248, Paris, Cedex 05, France. ${ }^{3}$ Université Paris Descartes, Sorbonne Paris Cité, 12 rue de l'école de Médecine, 75270 Paris, Cedex 06, France.

\section{Received: 3 August 2013 Accepted: 8 October 2013}

Published: 19 October 2013

\section{References}

1. Jemal A, Bray F, Center MM, Ferlay J, Ward E, Forman D: Global cancer statistics. CA Cancer J Clin 2011, 61:69-90.

2. Claus EB, Risch N, Thompson WD: Genetic analysis of breast cancer in the cancer and steroid hormone study. Am J Hum Genet 1991, 48:232-242.

3. Miki Y, Swensen J, Shattuck-Eidens D, Futreal PA, Harshman K, Tavtigian S, Liu Q, Cochran C, Bennett LM, Ding W, Bell R, Rosenthal J, Hussey C, Tran T, McClure M, Frye C, Hattier T, Phelps R, Haugen-Strano A, Katcher H, Yakumo K, Gholami Z, Shaffer D, Stone S, Bayer S, Wray C, Bogden R, Dayananth P,
Ward J, Tonin P, et al: A strong candidate for the breast and ovarian cancer susceptibility gene BRCA1. Science 1994, 266:66-71.

4. Wooster R, Bignell G, Lancaster J, Swift S, Seal S, Mangion J, Collins N, Gregory S, Gumbs C, Micklem G: Identification of the breast cancer susceptibility gene BRCA2. Nature 1995, 378:789-792.

5. Pharoah PD, Antoniou AC, Easton DF, Ponder BA: Polygenes, risk prediction, and targeted prevention of breast cancer. N Engl J Med 2008, 358:2796-2803.

6. Walsh T, King MC: Ten genes for inherited breast cancer. Cancer Cell 2007, 11:103-105.

7. Seal S, Thompson D, Renwick A, Elliott A, Kelly P, Barfoot R, Chagtai T, Jayatilake H, Ahmed M, Spanova K, North B, McGuffog L, Evans DG, Eccles D, Breast Cancer Susceptibility Collaboration (UK), Easton DF, Stratton MR, Rahman N: Truncating mutations in the Fanconi anemia J gene BRIP1 are low-penetrance breast cancer susceptibility alleles. Nat Genet 2006, 38:1239-1241.

8. Rahman N, Seal S, Thompson D, Kelly P, Renwick A, Elliott A, Reid S, Spanova K, Barfoot R, Chagtai T, Jayatilake H, McGuffog L, Hanks S, Evans DG, Eccles D, Breast Cancer Susceptibility Collaboration (UK), Easton DF, Stratton MR: PALB2, which encodes a BRCA2-interacting protein, is a breast cancer susceptibility gene. Nat Genet 2007, 39:165-167.

9. Foulkes WD: Inherited susceptibility to common cancers. N Engl J Med 2008, 359:2143-2153.

10. Howlett NG, Taniguchi T, Olson S, Cox B, Waisfisz Q, De Die-Smulders C, Persky N, Grompe M, Joenje H, Pals G, Ikeda H, Fox EA, D'Andrea AD: Biallelic inactivation of BRCA2 in Fanconi anemia. Science 2002, 297:606-609.

11. Levitus M, Waisfisz Q, Godthelp BC, de Vries Y, Hussain S, Wiegant WW Elghalbzouri-Maghrani E, Steltenpool J, Rooimans MA, Pals G, Arwert F, Mathew CG, Zdzienicka MZ, Hiom K, De Winter JP, Joenje H: The DNA helicase BRIP1 is defective in Fanconi anemia complementation group J. Nat Genet 2005, 37:934-935.

12. Reid S, Schindler D, Hanenberg H, Barker K, Hanks S, Kalb R, Neveling K, Kelly P, Seal S, Freund M, Wurm M, Batish SD, Lach FP, Yetgin S, Neitzel H, Ariffin $\mathrm{H}$, Tischkowitz M, Mathew CG, Auerbach AD, Rahman N: Biallelic mutations in PALB2 cause Fanconi anemia subtype FA-N and predispose to childhood cancer. Nat Genet 2007, 39:162-164.

13. Suwaki N, Klare K, Tarsounas M: RAD51 paralogs: roles in DNA damage signalling, recombinational repair and tumorigenesis. Semin Cell Dev Biol 2011, 22:898-905.

14. Vaz F, Hanenberg H, Schuster B, Barker K, Wiek C, Erven V, Neveling K, Endt D, Kesterton I, Autore F, Fraternali F, Freund M, Hartmann L, Grimwade D, Roberts RG, Schaal H, Mohammed S, Rahman N, Schindler D, Mathew CG: Mutation of the RAD51C gene in a Fanconi anemia-like disorder. Nat Genet 2010, 42:406-409.

15. Shamseldin HE, Elfaki M, Alkuraya FS: Exome sequencing reveals a novel Fanconi group defined by XRCC2 mutation. J Med Genet 2012, 49:184-186.

16. Meindl A, Hellebrand H, Wiek C, Erven V, Wappenschmidt B, Niederacher D, Freund M, Lichtner P, Hartmann L, Schaal H, Ramser J, Honisch E, Kubisch C, Wichmann HE, Kast K, Deissler H, Engel C, Müller-Myhsok B, Neveling K, Kiechle M, Mathew CG, Schindler D, Schmutzler RK, Hanenberg H: Germline mutations in breast and ovarian cancer pedigrees establish RAD51C as a human cancer susceptibility gene. Nat Genet 2010, 42:410-414.

17. Loveday C, Turnbull C, Ramsay E, Hughes D, Ruark E, Frankum JR, Bowden G, Kalmyrzaev B, Warren-Perry M, Snape K, Adlard JW, Barwell J, Berg J, Brady AF, Brewer C, Brice G, Chapman C, Cook J, Davidson R, Donaldson A, Douglas F, Greenhalgh L, Henderson A, Izatt L, Kumar A, Lalloo F, Miedzybrodzka Z, Morrison PJ, Paterson J, Porteous M, et al: Germline mutations in RAD51D confer susceptibility to ovarian cancer. Nat Genet 2011, 43:879-882.

18. Park DJ, Lesueur F, Nguyen-Dumont T, Pertesi M, Odefrey F, Hammet F, Neuhausen SL, John EM, Andrulis IL, Terry MB, Daly M, Buys S, Le Calvez-Kelm F, Lonie A, Pope BJ, Tsimiklis H, Voegele C, Hilbers FM, Hoogerbrugge N, Barroso A, Osorio A, Breast Cancer Family Registry, Kathleen Cuningham Foundation Consortium for Research into Familial Breast Cancer, Giles GG, Devilee P, Benitez J, Hopper JL, Tavtigian SV, Goldgar DE, Southey MC: Rare mutations in XRCC2 increase the risk of breast cancer. Am J Hum Genet 2012, 90:734-739. 13.

19. Hilbers FS, Wijnen JT, Hoogerbrugge N, Oosterwijk JC, Collee MJ, Peterlongo P, Radice P, Manoukian S, Feroce I, Capra F, Couch FJ, Wang X, Guidugli L, Offit K, Shah S, Campbell IG, Thompson ER, James PA, Trainer AH, Gracia J, Benitez J, van Asperen CJ, Devilee P: Rare variants in XRCC2 as breast cancer susceptibility alleles. J Med Genet 2012, 49:618-620. 
20. Johnson J, Healey S, Khanna KK, KConFab, Chenevix-Trench G: Mutation analysis of RAD51L1 (RAD51B/REC2) in multiple-case, non-BRCA1/2 breast cancer families. Breast Cancer Res Treat 2011, 129:255-263.

21. Caux-Moncoutier V, Castéra L, Tirapo C, Michaux D, Rémon MA, Laugé A Rouleau E, De Pauw A, Buecher B, Gauthier-Villars M, Viovy JL, StoppaLyonnet D, Houdayer C: EMMA, a cost- and time-effective diagnostic method for simultaneous detection of point mutations and large-scale genomic rearrangements: application to BRCA1 and BRCA2 in 1,525 patients. Hum Mutat 2011, 32:325-334.

22. Align-GVGD. http://agvgd.iarc.fr/agvgd_input.php.

23. Tavtigian SV, Deffenbaugh AM, Yin L, Judkins T, Scholl T, Samollow PB, de Silva D, Zharkikh A, Thomas A: Comprehensive statistical study of 452 BRCA1 missense substitutions with classification of eight recurrent substitutions as neutral. J Med Genet 2006, 43:295-305.

24. SIFT. http://sift.jcvi.org/

25. Kumar $P$, Henikoff $S, N g P C$ : Predicting the effects of coding nonsynonymous variants on protein function using the SIFT algorithm. Nat Protoc 2009, 4:1073-1081

26. Polyphen-2. http://genetics.bwh.harvard.edu/pph2/.

27. Adzhubei IA, Schmidt S, Peshkin L, Ramensky VE, Gerasimova A, Bork P, Kondrashov AS, Sunyaev SR: A method and server for predicting damaging missense mutations. Nat Methods 2010, 7:248-249.

28. Exome Variant Server. http://evs.gs.washington.edu/EVS/

29. 1000 Genomes. http://www.1000genomes.org/.

30. Houdayer C, Caux-Moncoutier V, Krieger S, Barrois M, Bonnet F, Bourdon V, Bronner M, Buisson M, Coulet F, Gaildrat P, Lefol C, Léone M, Mazoyer S, Muller D, Remenieras A, Révillion F, Rouleau E, Sokolowska J, Vert JP Lidereau R, Soubrier F, Sobol H, Sevenet N, Bressac-de Paillerets B, Hardouin A, Tosi M, Sinilnikova OM, Stoppa-Lyonnet D: Guidelines for splicing analysis in molecular diagnosis derived from a set of 327 combined in silico/in vitro studies on BRCA1 and BRCA2 variants. Hum Mutat 2012, 33:1228-1238

31. Heim S, Nilbert M, Vanni R, Floderus UM, Mandahl N, Liedgren S, Lecca U, Mitelman F: A specific translocation, $\mathrm{t}(12 ; 14)(\mathrm{q} 14-15 ; \mathrm{q} 23-24)$, characterizes a subgroup of uterine leiomyomas. Cancer Genet Cytogenet 1988, 32:13-17.

32. Schoenmakers EF, Huysmans C, van de Ven WJ: Allelic knockout of novel splice variants of human recombination repair gene RAD51B in $\mathrm{t}(12 ; 14)$ uterine leiomyomas. Cancer Res 1999, 59:19-23.

33. Date $O$, Katsura M, Ishida M, Yoshihara T, Kinomura A, Sueda T, Miyagawa K: Haploinsufficiency of RAD51B causes centrosome fragmentation and aneuploidy in human cells. Cancer Res 2006, 66:6018-6024.

34. Thomas G, Jacobs KB, Kraft P, Yeager M, Wacholder S, Cox DG, Hankinson SE, Hutchinson A, Wang Z, Yu K, Chatterjee N, Garcia-Closas M, Gonzalez-Bosquet J, Prokunina-Olsson L, Orr N, Willett WC, Colditz GA, Ziegler RG, Berg CD, Buys SS, McCarty CA, Feigelson HS, Calle EE, Thun MJ, Diver R, Prentice R, Jackson R, Kooperberg C, Chlebowski R, Lissowska J, et al: A multistage genome-wide association study in breast cancer identifies two new risk alleles at 1 p11.2 and 14q24.1 (RAD51L1). Nat Genet 2009, 41:579-584.

35. Orr N, Lemnrau A, Cooke R, Fletcher O, Tomczyk K, Jones M, Johnson N, Lord CJ, Mitsopoulos C, Zvelebil M, McDade SS, Buck G, Blancher C, KConFab Consortium, Trainer AH, James PA, Bojesen SE, Bokmand S, Nevanlinna H, Mattson J, Friedman E, Laitman Y, Palli D, Masala G, Zanna I, Ottini L, Giannini G, Hollestelle A, Ouweland AM, Novaković S, Krajc M, et al: Genome-wide association study identifies a common variant in RAD51B associated with male breast cancer risk. Nat Genet 2012, 44:1182-1184

36. Zucchero TM, Cooper ME, Maher BS, Daack-Hirsch S, Nepomuceno B, Ribeiro L, Caprau D, Christensen K, Suzuki Y, Machida J, Natsume N, Yoshiura K, Vieira AR, Orioli IM, Castilla EE, Moreno L, Arcos-Burgos M, Lidral AC, Field LL, Liu YE, Ray A, Goldstein TH, Schultz RE, Shi M, Johnson MK, Kondo S, Schutte BC, Marazita ML, Murray JC: Interferon regulatory factor 6 (IRF6) gene variants and the risk of isolated cleft lip or palate. N Engl J Med 2004, 351:769-780.

37. Dickson SP, Wang K, Krantz I, Hakonarson H, Goldstein DB: Rare variants create synthetic genome-wide associations. PLoS Biol 2010, 8:e1000294.

38. dbSNP. http://www.ncbi.nlm.nih.gov/SNP/.

39. He XF, Wei W, Su J, Yang ZX, Liu Y, Zhang Y, Ding DP, Wang W: Association between the $X R C C 3$ polymorphisms and breast cancer risk: metaanalysis based on case-control studies. Mol Biol Rep 2012, 39:5125-5134.

40. Thompson ER, Boyle SE, Johnson J, Ryland GL, Sawyer S, Choong DY, kConFab, Chenevix-Trench G, Trainer AH, Lindeman GJ, Mitchell G, James PA, Campbell IG: Analysis of RAD51C germline mutations in high-risk breast and ovarian cancer families and ovarian cancer patients. Hum Mutat 2012, 33:95-99.

41. Romero A, Pérez-Segura P, Tosar A, García-Saenz JA, Díaz-Rubio E, Caldés T, de la Hoya M: A HRM-based screening method detects RAD51C germline deleterious mutations in Spanish breast and ovarian cancer families. Breast Cancer Res Treat 2011, 129:939-946.

42. Loveday C, Turnbull C, Ruark E, Xicola RM, Ramsay E, Hughes D, WarrenPerry M, Snape K, Breast Cancer Susceptibility Collaboration (UK), Eccles D, Evans DG, Gore M, Renwick A, Seal S, Antoniou AC, Rahman N: Germline RAD51C mutations confer susceptibility to ovarian cancer. Nat Genet 2012, 44:475-476. author reply 476.

doi:10.1186/1471-2407-13-484

Cite this article as: Golmard et al:: Germline mutation in the RAD51B gene confers predisposition to breast cancer. BMC Cancer 2013 13:484.

\section{Submit your next manuscript to BioMed Central and take full advantage of:}

- Convenient online submission

- Thorough peer review

- No space constraints or color figure charges

- Immediate publication on acceptance

- Inclusion in PubMed, CAS, Scopus and Google Scholar

- Research which is freely available for redistribution 